\title{
Will You Covenant Marry Me? A Preliminary Look at a New Type of Marriage
}

\author{
Amanda J. Felkey \\ Department of Economics, Lake Forest College, Lake Forest, IL, 60045, USA.
}

In a backlash to the growing divorce rate, three states have begun to offer covenant contracts - a more binding form of legal marriage. From a policy and public finance standpoint, it is important to understand how covenant availability may change the marrying and divorcing behavior of couples. This paper serves as a preliminary analysis of covenant marriage contracts. It describes who is choosing these unions and why. It uses both standard and behavioral economic approaches to explore theoretically why whether couples are using this new type of marriage to signal to or screen potential partners, or perhaps as a commitment device. Empirical evidence suggests that this marriage may be a commitment device and draws into question whether or not this option is effective in its goal of creating stronger, happier unions, and decreasing divorce rates.

Eastern Economic Journal (2011) 37, 367-389. doi:10.1057/eej.2009.49; published online 28 February 2011

Keywords: covenant marriage; state marriage contracts; divorce rates

JEL: D10; K12; H70

\section{INTRODUCTION}

In an effort to combat growing divorce rates and create stronger, happier marriages, some states have begun to offer a stricter legal marriage contract called a covenant. Covenant marriages make more costly the divorce process - making them a seemingly apt remedy to growing divorce rates. But are they? And even if covenant marriages prove successful in strengthening the bond between husband and wife, ultimately lowering the divorce rate, are couples in them happier? Are the costs or benefits beyond those experienced by the couple using the covenant? Questions surrounding the possible trend toward stricter marriage contracts abound.

But before anyone can attempt to answer them, we need to understand who is marrying with these contracts and why. For instance, do younger couples marry with covenants or is their use driven by religion? Are potential mates using this new marriage as a way of signaling or screening their partner or is it rather a commitment device? The answers to these questions certainly affect the potential consequences for divorce rates. One might think that if younger couples are using this stricter marriage as a commitment device, the result may not be fewer divorces, just more costly ones. On the other hand, if couples are screening for some unobservable trait, like commitment, and covenants give them more information before marriage, they may be useful in their goal of stifling divorce and increasing happiness.

This paper serves as a preliminary exploration of the covenant marriage option and is the first systematic economic analysis of this new marriage. As the fundamental first step to understanding how covenant marriages will effect couples, 
this paper aims to (1) describe what a covenant marriage is and outline the debate surrounding this new type of marriage; (2) consider why couples might use this stricter and potentially more costly union; and (3) explore who is marrying with a covenant by comparing different populations of couples and empirically estimating what individual and couple characteristics affect the decision to use a covenant. This paper addresses each of these issues in turn.

Section two of this paper outlines what a covenant marriage is and comments on the debate surrounding this type of union. The third section considers why couples might choose the covenant marriage option. It offers competing theoretical explanations for why individuals may prefer the more binding contract. Section four uses marriage certificate data from Louisiana and Arkansas to determine empirically who is using the covenant option. It describes and compares subpopulations based on time as well as marriage and ceremony type, and utilizes a logit analysis to determine what couple and individual characteristics affect the decision to engage in a covenant marriage. This section sheds some light on why couples are choosing covenants. Section five concludes and outlines remaining questions.

\section{COVENANT MARRIAGE}

Before looking at why individuals may seek a covenant rather than a traditional marriage, let us first discuss how the two contracts differ. This section briefly explores the history of marriage and divorce law, giving insight into why this type of marriage has emerged in the United States. It then outlines the differences in the requirements made of couples engaging in covenants $v s$ traditional marriages. Finally, there is a review of the debate surrounding covenant marriages - this debate raises several political, legal, and social issues.

\section{A brief history of marriage and divorce law}

The original American divorce laws allowed the dissolution of marriage only when a strict set of requirements was met. These at-fault divorce laws were established when the states were merely colonies and governed divorces throughout the United States for more than 300 years [Cook 1998]. The strictness of separation legislation stemmed from the belief that "the family was the foundation of society and marriage the cornerstone" [Hamm 1999]. These stringent divorce laws and the conviction that marriage should be preserved attached a social stigma to divorce, one which waned over the twentieth century. As early as the 1940s, the US laws surrounding marriage and divorce began to evolve. Over the next three decades, the Supreme Court repeatedly struck down state laws that protected the family. This was the beginning of a national trend reducing the obstacles to divorce.

By the 1960s, there were several acceptable methods by which divorcees and lawyers could circumvent divorce statutes and nasty courtroom battles had run amuck. Attorneys often encouraged their clients to perjure themselves or set up residence out of state to take advantage of more lenient divorce laws. The "Commission on the Family," appointed by California's Governor Edmund Brown to investigate this growing problem, concluded that removing the fault requirement from legal divorce would not only eliminate the propensity for collusion and fraud by couples but also would ultimately decrease the divorce rate [Hamm 1999]. Hoping to bring divorce legislation in line with contemporary practice and reduce 
the hostility and bitterness permeating separation proceedings, California began the nationwide trend toward no-fault divorce law in 1969. The shift to a no-fault system had spread through all 50 states by 1985 .

The emergence of no-fault divorces had many consequences for both the processes of separation and divorce outcomes. A true no-fault system makes the decision to dissolve a marriage unilateral. When one party claims "irreconcilable differences," a divorce can be granted. This makes the consent of the spouse irrelevant and shifts power from the partner wanting to remain in the union to the partner seeking separation. Simultaneous to the nation's adoption of no-fault laws, the divorce rate rose by 34 percent between 1970 and 1990 [Hamm 1999]. This increase could be coincidental to no-fault divorces, a result of women entering the workforce and being less financially dependent on their spouses, or a direct effect of the decrease in costs. Economists have belabored this issue and have yet to settle on how much of the growth in the divorce rate can be attributed to the change in ease of exit. ${ }^{1}$

In a somewhat delayed backlash to the no fault divorce trend, some states have begun to offer covenant marriage contracts in addition to maintaining their traditional marriage option. Currently, covenant marriages are a legal option in three states. The first state to offer covenant marriage contracts was Louisiana, which passed its Covenant Marriage Law on June 23, 1997. Arizona passed a similar law in 1998 as did Arkansas in 2001. Though none have adopted the covenant option, many other states have repeatedly considered covenant marriage legislation -17 in 1998 and another 25 in 1999 [Mayer 1999].

\section{What is a covenant marriage?}

A covenant marriage is a legal contract that is more costly to enter and exit than is a traditional marriage. By engaging in a covenant marriage, couples agree to undergo premarital counseling. Once married, this more binding union compels a legal accountability for the promise of marriage by requiring that fault once again be shown for marriage dissolution. Covenantly married couples give up their right to a no-fault divorce. Fault grounds for the dissolution of a covenant contract include adultery, felony conviction, abandonment, abuse, a 2-year separation or passage of a specified period following a judgment of separation from bed and board. These grounds reflect the narrow statutory requirements of divorce laws before the 1970s. In addition to the stipulations about legal accountability, covenantly married spouses are required to be separated for a specified period of time and undergo marital counseling before a divorce will be granted.

In economic terms, the difference between being in a covenant or a traditional marriage is simple - there are increased costs associated with covenant marriages. First, it is more costly to enter, given the premarital counseling required. Second, it is certainly more costly to exit, as fault must be shown for the marriage to be dissolved. These higher exit costs limit the choice set of agents in covenant marriages relative to their traditionally married counterparts. And this limiting of choices can potentially have a negative impact on utility. Furthermore, the covenant contract increases the bargaining power of the individual wanting to remain married.

\section{The covenant debate}

The covenant marriage debate began as early as the late 1940s in the French parliament. The debate in France addressed many of the issues that still permeate 
today's covenant marriage debate [The First Covenant Debate 1947]. Proposing covenants as a marital option in France was an effort to save the family, combat growing divorce rates, and create stronger, happier marriages. This remains the contemporary impetus for the availability of these stricter marriage contracts. Advocates of covenant marriages hope that these unions will induce couples to take more seriously the commitment to their relationship and to be more devoted to making their marriages last [Leon 2004]. Besides merely trying to save the sanctity of marriage, many supporters of covenant marriage contracts aim to alleviate other problems. They note that the most tragic side effect of the increase in divorce rates is the growing number of children in single parent households.

Although the goals of such marriage legislation seem admirable, there are several credible arguments against the availability of covenant marriage contracts. At first glance, this may seem to be a debate that would fall strictly down party lines but interestingly it has opponents from all political arenas. ${ }^{2}$ There are, however, several arguments against the availability of covenant marriage contracts that have been posed by conservatives and liberals alike. Religious covenant marry opponents fear that offering a stronger marriage contract will cast a shadow over all traditional marriage contracts, even those previously granted. They are also concerned that couples will face pressure (both social and religious) to opt for the stricter union, leaving them to face more costly court battles if divorce is undertaken. Or perhaps, if couples feel pressure to covenant marry, they may instead choose to cohabitate rather than get married at all. This would exacerbate the already dramatic increase in the cohabitation rate - a rate that has increased 700 percent since 1970. The opponents of covenant marriages also worry that waiting periods will make it harder for spouses and children to leave abusive and neglectful relationships [Cook 1998; Leon 2004]. The Louisiana American Civil Liberties Union (ACLU) has consistently opposed covenant marriages because there would be an undue burden placed on women, who statistically make less money and have less control over household finances, during more costly divorce proceedings [Cook 1998]. On the other hand, economists have argued that unilateral divorces decreased the bargaining power of women being left by their husbands, leaving more women in poverty after divorce. If they effectively decrease the divorce rate, covenants could even help alleviate this problem.

Even for a couple that stays married there are concerns about covenant contracts. Lawyers have raised questions about the legal consequences of covenant marriage contracts. If some marriages are given "premium" status, it opens the door for discrimination to develop on the basis of marital type. Employers and insurance companies could give special consideration to covenant couples if they place value on stability (which they may believe exists to a greater extent in a covenant marriage). Even the government could distinguish between couples when it comes to taxation.

Finally, not all 50 states currently recognize the covenant marriage as an options. Individuals seeking to dissolve a covenant could do so in an alternate state. This inconsistency in marriage and divorce law between states mimics the situation created during the gradual shift to universal no-fault divorce laws. During the 1970s and 1980s, the states with the least stringent divorce laws became destinations for many separating couples and were referred to as divorce mills. 


\section{THEORETICAL EXPLANATIONS FOR CHOOSING A COVENANT MARRIAGE}

In order for couples to voluntarily restrict future choices with the stricter covenant marriage, it must provide them an additional benefit. Since there are currently no monetary benefits, in terms of tax breaks or lower insurance premiums, this benefit must come from changes to the expected value of the union. ${ }^{3}$ And there are two main ways in which this expected value could change: (1) there could be a better match between the individuals within the couple or (2) there could be an increase in the investment made by the married individuals. In the first case, covenant marriages may act as a signaling mechanism or screening device, by which individuals can gain additional information and create higher quality matches. In the second case, the covenant acts as a commitment device, ensuring individuals are more likely to invest in the union rather than exit the marriage. ${ }^{4}$ These two explanations yield somewhat different predictions about the couples that would use covenant marriages and the population of all marriages when covenants are available. The following subsections explore each explanation in turn and comment on how the predictions may be empirically tested.

\section{The signaling/screening explanation}

Individuals may be using covenant marriages as a way to signal to or screen potential partners. They may be providing individuals with a mechanism by which they can increase the information they have about their potential partners. In order to explore this explanation and its implication for marriage, let us assume that covenants are a credible signaling/screening device and that this is why couples are using them. ${ }^{5}$

To illustrate such a situation, let us consider a simple model of covenant marriage as a signaling/screening device. Let there be a spectrum of individual types based on commitment level or dedication to the union. This type varies with level of personal independence, determination, stamina, or any other personal characteristic that would make someone more or less likely to stick it out during potential rough patches in the marriage. Another possible way to think about this spectrum is that it includes a person's utility from being single. ${ }^{6}$ At one end of the spectrum are individuals with a high single person utility (let these individuals be low-dedication types) who will be willing to call it quits at relatively higher levels of marital utility. The other end of the spectrum includes people who consider divorce a last resort (high-dedication types). Individuals know their own type, but there is imperfect information about a potential mate's level of dedication. This seems realistic given couples spend time dating before taking the plunge.

As the expected value of a marriage incorporates the probability that it will end, there is a higher expected value when your partner is a more dedicated type. As long as this type affects either your potential marital happiness or the probability that you separate, screening for it will change your expected happiness in a marriage. In this set up, marriage itself acts as a signaling/screening device. It is a way for individuals to signal that they are dedicated to the match. Marriages will take place between individuals who are more dedicated and will not occur among couples where one or both of the partners are of a low-dedication type. This is illustrated by Figure 1.

In Figure 1, the dedication level of an individual increases as you move rightward along the spectrum of dedication. And there is some point $\mathrm{X}$, to the right of which an individual's dedication type translates into an expected value of the marrying that 


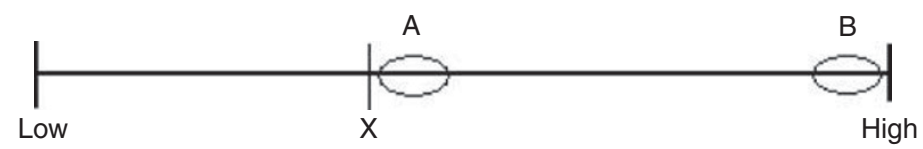

Figure 1. Dedication spectrum without covenant marriages.

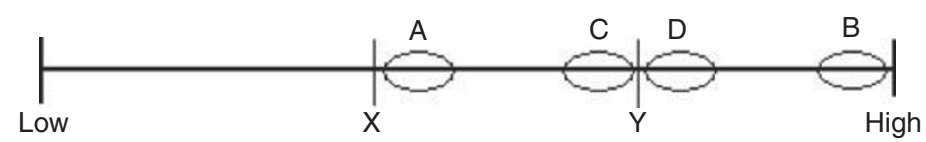

Figure 2. Dedication spectrum with covenant marriages.

is larger than that of remaining in the unmarried partnership. Below that point are less dedicated types, who will find marriage an unappealing option. As you can see, individuals with a relatively high-dedication type will marry each other, while those of lower dedication types will not. For instance, person A will marry person B. But marriages will not include individuals to the left of $X$ because they will not want to make the extra commitment.

Along these lines, the covenant marriage option provides another way in which individuals can gather more information about their potential partner's type. Since covenant marriages increase the costs associated with divorce (and as long as this cost is sufficiently higher than those under the traditional contract), they provide another way in which individuals can gain information about dedication type. Only the most dedicated type of individuals, who do not think that they will divorce, are willing to engage in these arrangements. This additional contract allows individuals to further distinguish individual types. Figure 2 illustrates this idea.

In this figure, there is a new point, Y, separating the dedication types according to those willing and unwilling to engage in a covenant marriage. In this situation, person B can screen potential partner A by asking for a covenant. Person A will decline because her dedication level is too low for a covenant to be appealing. And individuals $\mathrm{A}$ and $\mathrm{B}$ will not get married. The couples that will emerge from this situation will be $\mathrm{A}$ and $\mathrm{C}$, who will marry traditionally, and $\mathrm{B}$ will marry $\mathrm{D}$ with a covenant marriage.

Basically, the covenant marriage option adds another tool by which individuals can gather information and hone their match. This means if individuals are using covenants to signal or screen partners, there will be an increase in positive assortative mating. Couples will be more similar along the dimension upon which covenants screen.

It is relatively straightforward to mathematically formalize this explanation for covenant use and solve for a Bayesian Nash Equilibrium. The best strategy is to request a covenant marriage if you are a high-dedication-type, so individuals that are a type match will agree to the covenant and individuals of a lower type will decline to engage in the arrangement. Also, if you are a low-dedication-type, you will not ask for the covenant (signaling your type in this case as well) and will marry a same type person with a traditional marriage.

The result of this approach implies that the mere existence of the covenant marriage option will fundamentally change the population of marriages. The first implication of this model is that only high-dedication-type people will use a 
covenant marriage. So couples in covenants will be more similar, and they will be different from couples that marry traditionally. Second, because there exists a signaling device that was previously not available, the population of all marriages will be different before and after the covenant marriage option. Since the Bayes Nash Equilibrium implies that only people of similar type will marry, we should no longer see unions between individuals who differ greatly, as Figure 2 illustrates. This will lead to a notable trend among married couples. Marriages will be between more similar individuals (in terms of the type upon which individuals are screening) after 1997 than before.

\section{The commitment device explanation}

Agreeing to marital counseling and the extended waiting period for separation that characterizes the covenant marriage provides scope for individuals using covenant contracts as a commitment device. Individuals may be protecting themselves against their own future "irrationalities" by choosing the stricter covenant contract. Marrying agents may understand that visceral factors can exacerbate the time inconsistency in their preferences and appreciate the critical role that emotions can play when they make decisions [Loewenstein, 2000; Camerer et al. 2003; Loewenstein et al. 2003; O'Donoghue and Rabin, 2003]. Being affected by these decision altering, visceral factors puts individuals into what has been called a biologically "hot" state [Camerer et al. 2003; O'Donoghue and Rabin, 2003]. Responding to such emotions is not necessarily a mistake given concerns for current well-being; however, decisions made in "the heat of the moment" may have future consequences that are not appropriately taken into account when the person is in their "hot" state. "Hot" state behavior seems appropriate to consider when analyzing the decisions to marry or divorce. Engaging in or terminating a long-term relationship with another person is undoubtedly a decision flocked with visceral factors - the euphoria of being in love, lust for another individual, or the overwhelming anger felt while fighting with your spouse.

Though individuals seem to heavily discount the future when making a decision in their "hot" state, they are not unaware that they may fall victim to such urges. As a result, mechanisms have developed to protect individuals from potential indiscretions - covenant marriages may be one of these mechanisms. Covenant marriages may be a commitment device in which individuals voluntarily engage to limit future actions, with the hope that these actions will be in line with their long-term goals. One desirable characteristic of a covenant marriage as a commitment device is its provision of a cooling-off period for individuals in a "hot" state and contemplating divorce. Covenant contracts are mechanisms by which individuals can temper the decisions made when they are angry and spiteful.

The benefit provided by a covenant marriage depends on the weight that the individuals give to their visceral factors when making decisions or how susceptible they are to having "hot" states. Consider a world where no one suffers from "hot" states. Covenant marriages provide no benefit if individuals are unaffected by visceral factors and always make "rational" and perfectly time-consistent decisions. In this case, individuals have no need for a commitment device on behavior and covenants would merely place undue restrictions on their decision making. Now consider the other extreme, where all individuals are highly influenced by visceral factors, which they experience often. In a world filled with highly emotional individuals, where people are easily "set off" and quick to make "rash" decisions, covenant marriages could be quite beneficial for long-term utility. Reality lies 
somewhere between these two worlds - realistically, everyone is affected to some degree by biological "hot" states. Since the bounded rationality of people varies, so do the individual benefits from the restrictions put on their own decisions by the covenant - the more emotional a person is the more likely they are to benefit from the covenant as a commitment device.

Notably, the benefits of the covenant commitment device are not solely enjoyed by the bondedly rational, but are also enjoyed by those who form partnerships with such individuals. To demonstrate this point, let there be two types of people - fully rational and boundedly rational individuals (this is the same simplifying assumption made by Camerer et.al.). It is trivial that for two fully rational individuals, a covenant is not an appealing option since neither partner is worried that they will make decisions they may regret. It is also trivial that couples where each partner is boundedly rational may find the covenant option undoubtedly superior to the traditional option. The interesting case is when one partner is fully rational and the other is boundedly so. The boundedly rational partner reaps benefit from restrictions placed on their behavior, as already discussed, but the fully rational partner also benefits from these restrictions. Though there is no need to restrict the rational partner's behavior, they now enjoy the security that comes from the fact their "hot-headed" partner will not leave them at the first sign of conflict. As long as the costs of restriction on their own behavior do not outweigh the benefit of the restriction on their partner's behavior, they will enter into a covenant with their boundedly rational partner and be better off as a result of the commitment device. When you consider that marriage and divorce are commitments made for a lifetime, it seems realistic that the cost of waiting mere months for a divorce will seem trivial to a rational person.

By relaxing the assumption that there are merely two types of individuals distinguishable by rationality, we can explore how couples may choose their marriage type based on each partners' rationality. Consider another spectrum, this time measuring rationality boundedness. Figure 3 illustrates the spectrum of individual rationality boundedness, which is low on the right and high on the left. This means that individuals on the left of the spectrum are highly boundedly rational and largely affected by their visceral factors and "hot" states. On the other end of the spectrum are individuals who exhibit close to no "hot" state behavior - their rationality is not bounded.

Just like rationality boundeness varies along this spectrum so does potential benefit from a marital commitment device - those who are more boundedly rational gain more benefits from covenants. Point Y indicates some point at which the boundedness of an individual's rationality (moving left on the spectrum) becomes large enough for a commitment device to be a desirable option. In this scenario, any combination of individuals may marry. If B and D marry, we can conclude that it is with a traditional marriage because neither find the commitment device worthwhile. If A and C marry, it will certainly be with a covenant since they both find the commitment device worthwhile. Because both partners gain utility

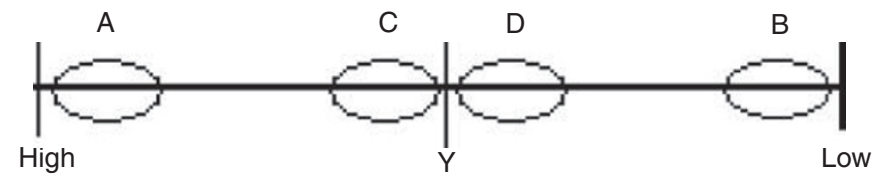

Figure 3. Rationality boundedness spectrum. 
from the commitment device when at least one of them is boundedly rational, we may see A marry B with a covenant marriage.

From this behavioral economic explanation of the covenant marriage decision, there are a couple of notable predictions about marriages outcomes. First, there should be little or no change to the population of marriages that occur. There is no reason to believe that the composition of married couples will change, because fully rational individuals will marry both other fully rational individuals and boundedly rational individuals alike, as would be the expectation without the covenant option. The same is true for boundedly rational individuals - they will also marry both types of people. Second, if individuals are using covenant marriages as a commitment device, we can anticipate that couples of different type composition will marry. Fully rational couples will marry with traditional contracts and boundedly rational couples will marry using a covenant (with some restrictions on them being too costly to exit to be a worthwhile commitment device). Couples that have one fully rational individual and one boundedly rational individual will marry both ways depending on the relative costs and benefits associated with their relative degrees of rationality. What is interesting is that couples consisting of rationally divergent individuals could use covenants. And this result differs from the prediction of the signaling/screening explanation - the prediction that marrying individuals will be more similar.

\section{Testable implications and empirical limitations}

The two explanations outlined above offer somewhat competing predictions about couples marrying with a covenant and all couples marrying after covenants became available. The signaling/screening model tells us that individuals within a covenantly married couple will be more similar, as will all marrying couples after legislation. The commitment device explanation indicates that individuals who marry with a covenant could be more, less or even equally alike, and there is no reason to believe that the population of all couples marrying will change as a result of this option. Given these theoretical predictions, it will be possible to reject that individuals are marrying with covenants to signal or screen one another, but we are limited in directly testing the commitment device approach because the population of individuals who marry will not necessarily be affected. We can, however, say that the commitment device explanation is superior if we find that individuals within this stricter union are less similar — this would be evidence to reject the signaling explanation of covenant use.

The empirical section of this paper first explores how the population of couples marrying has changed since the covenant option and then estimates a demand for covenant marriages based on individual and couple characteristics. In the former, a finding that individuals within marrying couples are more different would be evidence that covenants are not used for screening or signaling. And in the latter, if the demand for this stricter marriage increases with differences within couples, they are more likely using the union as a commitment device rather than a mechanism by which to gather more information about their match.

If type can be identified by observable personal characteristics, we can test whether or not the couples that marry covenantly or traditionally are statistically different when the covenant marriage is an option. If we correspond the dimension upon which individuals are signaling and screening type with information about individuals within the data, we can test the predictions 
of this explanation. For instance, let us say that one type is generally more educated - perhaps because achieving an additional degree requires some amount of endurance or stamina that would correspond to one's propensity to stay in a marriage. In the situation where individuals are screening, we could expect that highly educated people only marry other highly educated people and those with lower education levels to marry each other - people are more similar in terms of type. On the other hand, if couples are using covenants as a commitment device, then they could be more different along this dimension. The assumption about education and type used in this illustration is only critical in that it differentiates one type from another - it is not essential which type is associated with each specific level of education. (Note that the degree to which personal characteristics will converge is dependent on how correlated the observed characteristic is with individual type or bounded rationality.)

The obvious drawback to this approach is the use of an observable characteristic as a proxy for unobservable type. If this is really a good proxy, then individuals could potentially use this as a signal and do not need a covenant. This limitation of the analysis cannot be avoided with the limited amount of data and its administrative nature. So, testing whether there is signaling/screening requires the rather unrealistic assumption that there is something unobservable about their partner that can be measured in this analysis with characteristics reported on marriage certificates. Additionally, the following empirical analysis assumes that there is positive assortative mating and individuals are signaling/screening to ensure that they marry someone more similar along some dimension. If this were not the case, and they were seeking individuals more different than themselves, then the implications for this explanation would not be discernable from that of the commitment device.

\section{EMPIRICAL ANALYSIS OF THE CHOICE TO COVENANT MARRY}

This section empirically analyzes the decision to covenant marriage using administrative data from two of the states that offer this alternative form of marriage, Louisiana and Arkansas. The following subsections use administrative data from these states to explore the utilization of the covenant marriage option. The first subsection describes and summarizes marriage certificate data from Louisiana and Arkansas from 1990 to 2003. It provides summary statistics, illustrates the time series of covenant use, and compares subsets of the marrying population (by time, marriage type, and ceremony type). The second subsection presents the estimation of the couple's decision to covenant marry. The following empirical analysis relies on the fact that we can observe some monotonic transformation of individual type in the available data. It requires the assumption that the individual characteristics we observe from the marriage certificates indicates the type along the dimension for which individuals are screening or an individual's degree of rationality boundedness.

\section{Louisiana and Arkansas marriage certificate data}

This analysis uses administrative data collected from marriage license applications. In both Arkansas and Louisiana, a couple must acquire a marriage license before their nuptials. The requirements for obtaining a Louisiana marriage certificate 
include a copy of each partner's birth certificate, their social security numbers, parents' full names, mother's maiden name, and state in which they were born. The Arkansas marriage license can be acquired without any of this information. Neither states' marriage license requires either partner be a state resident nor do they require blood tests. Arkansas has no waiting period, but Louisiana residents must wait a mandatory 72 hours between the issuance of the marriage license and the ceremony. This waiting period is waived for out-of-state couples getting married in New Orleans. All licenses are good for 30 days anywhere in Louisiana and 60 days anywhere in Arkansas. In both states, if either member of the couple was married previously that individual must show proof of how the prior marriage ended, that is, a certified divorce judgment or certificate of death. Finally, marriage licenses are not granted without a court order if either of the parties is less than 16 years old. If either party is between the ages of 16 and 18 years, then the presence and signature of both parents is required for the license to be issued (and a birth certificate may me necessary to verify age in Arkansas).

Louisiana does not require that both parties be present when applying for a marriage license, unless the couple is applying for a covenant marriage. If seeking a license for a traditional marriage, either the bride or groom can apply and simply present the birth certificate for their partner. Covenant marriage licenses, on the other hand, require that both parties apply in person and sign up for premarital counseling. Arkansas has no such requirement.

The Louisiana data come from the Office of Public Health Statistics in New Orleans where personal information about all marrying couples is collected as part of the Vital Records Marriage System. The data include all marriages that have occurred in the State of Louisiana from 1990 through 2003. For this analysis, only the information about Louisiana resident marriages is used. If both the bride and the groom are residents of other states, their marriage information is omitted. Over the period 1990-2003, approximately 35,000 of Louisiana's marriages were between two non-residents - this accounts for less than 7 percent of all the marriages. Nonresidents marrying in Louisiana with a covenant faced a fundamentally different decision than residents marrying with a covenant because they will most likely not be held accountable for the stricter legal union in their home states.

\section{Description of the data and means comparisons}

Since they became available, covenant marriages have been chosen by roughly one in one hundred marrying Louisiana couples. Table 1 reports the incidence of covenant marriage in Louisiana along with the percent of marriages that are covenant

The highest proportion of covenants occurred in the first full year of its availability, perhaps because some already married couples chose to change the status of their marriages, which would have acted like pent-up demand for this option. ${ }^{7}$ The rate at which couples are marrying with a covenant has declined since 1998, but remained steady around 1 percent. Figure 4 illustrates the trend in the proportion of all marriages that are covenant.

The Louisiana marriage certificate data are surprisingly rich and include information about the couple's marriage (when and where they exchanged vows, type of ceremony, and whether they chose a covenant or traditional contract), as well as personal information about each individual getting married. Individual information includes race, years of education at time of marriage, age, and prior 
Table 1 Louisiana covenant marriage use (1997-2003)

\begin{tabular}{lcc}
\hline Year & Marriages & Percent covenant \\
\hline $1997^{*}$ & 19,446 & 0.71 \\
1998 & 36,819 & 1.60 \\
1999 & 38,440 & 1.27 \\
2000 & 37,244 & 1.23 \\
2001 & 34,375 & 1.07 \\
2002 & 33,345 & 0.92 \\
2003 & 33,752 & 1.17 \\
\hline
\end{tabular}

*Marriages after July 23, 1997.

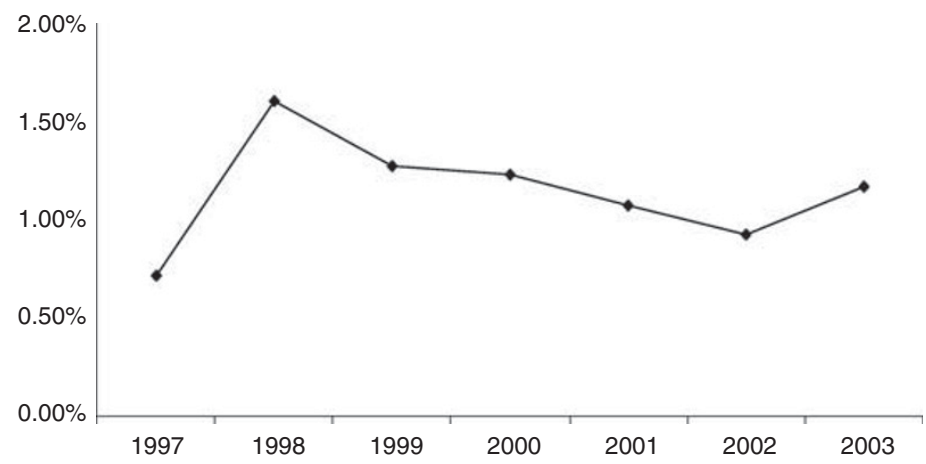

Figure 4. Time series of percent covenant marriages (1997-2003).

marital status. The data also include information about the date of each partner's birth and their birth states. The first two columns of Table 2 summarize the individual and couple characteristics for all Louisiana marriages between 1990 and $2003 .^{8}$

During these 14 years, the average couple that married in Louisiana was comprised of a 30-year old bride and a groom between 32 and 33 years of age. The average age difference between partners is about 4.5 years. Both the bride and the groom have approximately 13 years of schooling, and the average difference in education is less than a year and a half. Almost half of the couples opted for a civil rather than a religious marriage ceremony. In the whole sample of Louisiana marriages, 22 percent were comprised of two individuals who had both been previously divorced and 25 percent were between one partner who had been divorced and one who had not. Approximately 44 percent of the brides and grooms reside in urban areas. There are twice as many white brides and grooms as there are black, and 3 percent of the couples marrying between 1990 and 2003 in Louisiana are interracial.

The last four columns provide summaries for two subpopulations of couples; those marrying before and after the covenant option became available. All of the means are statistically significantly different at the 1 percent level, save the difference in education within couples and the dummy variable indicating that only one partner has been divorced. This is not surprising given the large sizes of each sample. More than half of the couples in the sample were married before covenant marriages were an option (approximately 55 percent), and since only 1 percent of 
Table 2 Summary statistics for all marriages in Louisiana (1990-2003)

\begin{tabular}{|c|c|c|c|c|c|c|}
\hline & \multicolumn{2}{|c|}{$\begin{array}{c}\text { All marriages } \\
(517,908)\end{array}$} & \multicolumn{2}{|c|}{$\begin{array}{l}\text { Before the covenant } \\
\text { option }(284,487)\end{array}$} & \multicolumn{2}{|c|}{$\begin{array}{l}\text { After the covenant } \\
\text { option }(233,421)\end{array}$} \\
\hline & Mean & s.d. & Mean & s.d. & Mean & s.d. \\
\hline Covenant & & & & & 0.012 & 0.108 \\
\hline Civil ceremony & 0.470 & 0.499 & 0.391 & 0.488 & 0.566 & 0.496 \\
\hline \multicolumn{7}{|l|}{ Resides in an urban area } \\
\hline Groom & 0.441 & 0.497 & 0.480 & 0.500 & 0.394 & 0.489 \\
\hline Bride & 0.448 & 0.497 & 0.485 & 0.500 & 0.404 & 0.491 \\
\hline Difference & 0.068 & 0.252 & 0.076 & 0.265 & 0.059 & 0.236 \\
\hline \multicolumn{7}{|l|}{ Race } \\
\hline Groom is black & 0.283 & 0.450 & 0.267 & 0.442 & 0.304 & 0.460 \\
\hline Bride is black & 0.277 & 0.448 & 0.263 & 0.440 & 0.296 & 0.457 \\
\hline Groom is white & 0.703 & 0.457 & 0.723 & 0.448 & 0.683 & 0.465 \\
\hline Bride is white & 0.707 & 0.455 & 0.726 & 0.446 & 0.689 & 0.463 \\
\hline Couple is interracial & 0.029 & 0.168 & 0.024 & 0.152 & 0.035 & 0.185 \\
\hline \multicolumn{7}{|c|}{ Education (absolute value of years) } \\
\hline Groom & 12.8 & 2.36 & 12.8 & 2.39 & 12.9 & 2.31 \\
\hline Bride & 13.0 & 2.25 & 12.9 & 2.25 & 13.2 & 2.23 \\
\hline Difference & 1.46 & 1.62 & 1.46 & 1.63 & 1.46 & 1.61 \\
\hline \multicolumn{7}{|c|}{ Age (absolute value of years) } \\
\hline Groom & 32.4 & 11.3 & 31.7 & 11.1 & 33.4 & 11.6 \\
\hline Bride & 30.0 & 10.4 & 29.2 & 10.0 & 30.9 & 10.7 \\
\hline Difference & 4.56 & 4.72 & 4.52 & 4.70 & 4.61 & 4.73 \\
\hline \multicolumn{7}{|l|}{ Previous divorces } \\
\hline Groom & 0.345 & 0.476 & 0.346 & 0.476 & 0.374 & 0.484 \\
\hline Bride & 0.343 & 0.475 & 0.346 & 0.476 & 0.369 & 0.483 \\
\hline One partner & 0.251 & 0.433 & 0.255 & 0.436 & 0.253 & 0.435 \\
\hline Both partners & 0.219 & 0.413 & 0.219 & 0.414 & 0.241 & 0.428 \\
\hline
\end{tabular}

couples married with a covenant. More couples are opting for civil rather than religious ceremonies (57 percent after 1997 and 39 percent before). Not surprisingly, couples are marrying older and with more education. ${ }^{9}$

Table 2 also provides the first evidence as to whether covenants are acting as a signaling/screening or commitment device. Recall that if individuals are using this marriage as a signaling/screening device, then we would expect the population of couples marrying will be more similar after the option's availability. This is not the case. There are five variables that measure several types of differences within couples residence in an urban area, race, education, age, and previous divorces. There are more than 10 percent more interracial couples. Individuals marrying are further apart in age, by a little over a month. The education difference between individuals is not smaller but the same. The point estimate for one individual having a prior divorce and the other not is smaller, but the difference is not statistically significant. The only significant variable indicating more similarity within couples after covenants is the indicator of residence in an urban area. The fact that couples are not generally more similar after covenants became available provides evidence that individuals are not using them as a signaling/screening mechanism, and the commitment device explanation is superior.

The Arkansas data, acquired from the Center for Health Statistics, Arkansas Department of Health, is much less rich - due to the fact that much less information is required of individuals when they are applying for a marriage license. 
Table 3 Summary statistics for all marriages in Arkansas (1990-2003)

\begin{tabular}{|c|c|c|c|c|c|c|}
\hline & \multicolumn{2}{|c|}{$\begin{array}{c}\text { All marriages } \\
(504,013)\end{array}$} & \multicolumn{2}{|c|}{$\begin{array}{c}\text { Before the covenant } \\
\text { option }(387,150)\end{array}$} & \multicolumn{2}{|c|}{$\begin{array}{l}\text { After the covenant } \\
\text { option }(116,863)\end{array}$} \\
\hline & Mean & s.d. & Mean & s.d. & Mean & s.d. \\
\hline Covenant & & & & & 0.005 & 0.071 \\
\hline \multicolumn{7}{|c|}{ Age (absolute value of years) } \\
\hline Groom & 33.5 & 12.7 & 33.2 & 12.6 & 34.5 & 12.9 \\
\hline Bride & 31.0 & 11.8 & 30.7 & 11.7 & 32.0 & 12.1 \\
\hline Difference & 5.00 & 5.04 & 5.00 & 5.06 & 5.01 & 4.97 \\
\hline
\end{tabular}

Table 3 summarizes the Arkansas marriage certificate data in the same way Table 2 summarized the data from Louisiana.

During the same period, the average age of individuals getting married in Arkansas was higher than in Louisiana. The age of the average bride was 31 years and that of the average groom was 33.5 years. And there is a 5-year age difference between individuals in the average marriage. Covenant marriages were only offered in the last 3 years of the 1990-2003 period in Arkansas, and about one half of a percent of marriages in those 3 years were covenant marriages. Like in Louisiana, brides and grooms in Arkansas are older after the availability of the covenant option and their age difference is larger. In Arkansas, however, this difference is not statistically significant.

It is also interesting to consider how the populations of couples may differ by marriage type. The next table (Table 4) summarizes couple characteristics by marriage type from the date covenant marriages were instituted through 2003. The first two columns summarize all marriages in Louisiana after July 23, 1997, they provide the same information as the last two columns of Table 2. The remaining four columns summarize the two subpopulations of individuals, those that married traditionally and those that married with a covenant.

All of the point estimates are statistically significantly different at the 1 percent level. From July 1997 to 2003, 1.2 percent of all marriages were covenant and 56 percent of them were the result of a civil ceremony; slightly more traditionally marrying couples chose to have a civil rather than religious ceremony. Covenantly married couples are more different in terms of residence type, almost twice as many couples are made up of one individual from an urban area and one who is not. Both brides and grooms in covenant marriages are younger and their age difference is smaller. The average bride and groom in the covenant marrying subsample have approximately 14 years of education and the difference between their educational attainments is on average about a year and a half. Couples in covenants are more educated but have a larger difference in their education levels than do their traditionally marrying counterparts. In the population of covenant married couples, 21 percent have one partner that was previously divorced and 19 percent are comprised of two previously divorced individuals. These proportions are both smaller than for the traditionally married population.

These summaries provide mixed evidence for rejecting the signaling/screening explanation. First, they indicate that covenant couples are less similar in terms of educational attainment and whether or not they reside in an urban area before the union. This is evidence against the signaling/screening explanation and support for the alternative, the commitment device explanation. Means tests indicate, 
Table 4 Marriages in Louisiana after the covenant option (mid-1997-2003)

\begin{tabular}{|c|c|c|c|c|c|c|}
\hline & \multicolumn{2}{|c|}{$\begin{array}{c}\text { All marriages } \\
(233,421)\end{array}$} & \multicolumn{2}{|c|}{$\begin{array}{c}\text { Traditional marriages } \\
(230,678)\end{array}$} & \multicolumn{2}{|c|}{$\begin{array}{c}\text { Covenant marriages } \\
\qquad(2,743)\end{array}$} \\
\hline & Mean & s.d. & Mean & s.d. & Mean & s.d. \\
\hline Covenant & 0.012 & 0.108 & & & & \\
\hline Civil ceremony & 0.566 & 0.496 & 0.566 & 0.496 & 0.560 & 0.497 \\
\hline \multicolumn{7}{|l|}{ Resides in an urban area } \\
\hline Groom & 0.394 & 0.489 & 0.394 & 0.489 & 0.397 & 0.489 \\
\hline Bride & 0.404 & 0.491 & 0.404 & 0.491 & 0.420 & 0.494 \\
\hline Difference & 0.589 & 0.236 & 0.059 & 0.235 & 0.100 & 0.300 \\
\hline \multicolumn{7}{|l|}{ Race } \\
\hline Groom is black & 0.304 & 0.460 & 0.305 & 0.461 & 0.162 & 0.366 \\
\hline Bride is black & 0.296 & 0.457 & 0.298 & 0.457 & 0.159 & 0.374 \\
\hline Groom is white & 0.683 & 0.465 & 0.682 & 0.446 & 0.832 & 0.374 \\
\hline Bride is white & 0.689 & 0.463 & 0.687 & 0.444 & 0.834 & 0.372 \\
\hline Couple is interracial & 0.035 & 0.185 & 0.036 & 0.185 & 0.023 & 0.150 \\
\hline \multicolumn{7}{|c|}{ Education (absolute value of years) } \\
\hline Groom & 12.9 & 2.31 & 12.9 & 2.31 & 13.8 & 2.24 \\
\hline Bride & 13.2 & 2.23 & 13.2 & 2.23 & 14.2 & 2.10 \\
\hline Difference & 1.46 & 1.61 & 1.46 & 1.61 & 1.50 & 1.55 \\
\hline \multicolumn{7}{|c|}{ Age (absolute value of years) } \\
\hline Groom & 33.4 & 11.6 & 33.4 & 11.6 & 30.4 & 9.93 \\
\hline Bride & 30.9 & 10.7 & 30.9 & 10.7 & 28.2 & 9.12 \\
\hline Difference & 4.61 & 4.73 & 4.62 & 4.73 & 3.84 & 4.08 \\
\hline \multicolumn{7}{|l|}{ Previous divorces } \\
\hline Groom & 0.374 & 0.484 & 0.374 & 0.484 & 0.314 & 0.464 \\
\hline Bride & 0.369 & 0.483 & 0.370 & 0.483 & 0.293 & 0.455 \\
\hline One partner & 0.253 & 0.435 & 0.254 & 0.435 & 0.214 & 0.410 \\
\hline Both partners & 0.241 & 0.428 & 0.241 & 0.428 & 0.192 & 0.394 \\
\hline
\end{tabular}

however, that individuals within covenant couples are more similar in terms of race, age, and prior divorces, which provides no evidence about which explanation is superior

For Arkansas, the results are similar. The individuals that marry covenantly in Arkansas are on average younger and closer in age than those that marry with traditional contracts. They are reported in Table 5.

A common prior is that covenants are driven by religion. With the available data, it is impossible to directly test whether or not this is the case. There is no information on the marriage certificate about religious status or flavor. The application for a marriage license does, however, require couples to indicate with what type of ceremony they will be marrying. They are able to indicate that they will be having a civil or religious ceremony. It seems reasonable that more religious individuals would favor the latter, while individuals less so will prefer the former. This analysis uses ceremony type as a proxy for the effect religion has on covenant usage. Table 6 separates couples into two subpopulations based on the type of ceremony they chose.

What is most interesting is that covenant marriages are chosen at the same rate by those marrying with each type of marriage, which indicates that religion may not be the primary factor in the decision to marry with a covenant. Besides residing in an urban area, there are no substantial differences between these two populations in Louisiana. 
บ. Amanda J Felkey

382

Will You Covenant Marry Me?

Table 5 Summary statistics for marriages in Arkansas by type (2001-2003)

\begin{tabular}{|c|c|c|c|c|c|c|}
\hline & \multicolumn{2}{|c|}{$\begin{array}{l}\text { All marriages } \\
(79,526)\end{array}$} & \multicolumn{2}{|c|}{$\begin{array}{c}\text { Traditional marriages } \\
(79,122)\end{array}$} & \multicolumn{2}{|c|}{$\begin{array}{c}\text { Covenant } \\
\text { marriages (404) }\end{array}$} \\
\hline & Mean & s.d. & Mean & s.d. & Mean & s.d. \\
\hline Covenant & 0.005 & 0.071 & & & & \\
\hline \multicolumn{7}{|c|}{ Age (absolute value of years) } \\
\hline Groom & 34.656 & 12.957 & 34.685 & 12.965 & 28.899 & 9.707 \\
\hline Bride & 32.074 & 12.153 & 32.101 & 12.161 & 26.881 & 9.047 \\
\hline Difference & 5.023 & 5.047 & 5.031 & 5.052 & 3.374 & 3.360 \\
\hline
\end{tabular}

Table 6 Marriages by ceremony type (mid-1997-2003)

\begin{tabular}{|c|c|c|c|c|c|c|}
\hline & \multicolumn{2}{|c|}{$\begin{array}{c}\text { All marriages } \\
(233,421)\end{array}$} & \multicolumn{2}{|c|}{$\begin{array}{c}\text { Civil ceremonies } \\
(132,104)\end{array}$} & \multicolumn{2}{|c|}{$\begin{array}{c}\text { Religious ceremonies } \\
(101,317)\end{array}$} \\
\hline & Mean & s.d. & Mean & s.d. & Mean & s.d. \\
\hline Covenant & 0.012 & 0.108 & 0.012 & 0.108 & 0.012 & 0.108 \\
\hline Civil ceremony & 0.566 & 0.496 & & & & \\
\hline \multicolumn{7}{|l|}{ Resides in an urban area } \\
\hline Groom & 0.394 & 0.489 & 0.361 & 0.480 & 0.438 & 0.496 \\
\hline Bride & 0.404 & 0.491 & 0.369 & 0.483 & 0.449 & 0.497 \\
\hline Difference & 0.589 & 0.236 & 0.054 & 0.227 & 0.066 & 0.248 \\
\hline \multicolumn{7}{|l|}{ Race } \\
\hline Groom is black & 0.304 & 0.460 & 0.303 & 0.460 & 0.304 & 0.460 \\
\hline Bride is black & 0.296 & 0.457 & 0.296 & 0.457 & 0.296 & 0.460 \\
\hline Groom is white & 0.683 & 0.465 & 0.683 & 0.465 & 0.683 & 0.465 \\
\hline Bride is white & 0.689 & 0.463 & 0.689 & 0.463 & 0.688 & 0.463 \\
\hline Couple is interracial & 0.035 & 0.185 & 0.036 & 0.186 & 0.035 & 0.184 \\
\hline \multicolumn{7}{|c|}{ Education (absolute value of years) } \\
\hline Groom & 12.9 & 2.31 & 12.9 & 2.31 & 12.9 & 2.30 \\
\hline Bride & 13.2 & 2.23 & 13.2 & 2.24 & 13.1 & 2.22 \\
\hline Difference & 1.46 & 1.61 & 1.46 & 1.62 & 1.45 & 1.61 \\
\hline \multicolumn{7}{|c|}{ Age (absolute value of years) } \\
\hline Groom & 33.4 & 11.6 & 33.4 & 11.7 & 33.3 & 11.5 \\
\hline Bride & 30.9 & 10.7 & 30.9 & 10.7 & 30.8 & 10.6 \\
\hline Difference & 4.61 & 4.73 & 4.59 & 4.73 & 4.64 & 4.77 \\
\hline \multicolumn{7}{|l|}{ Previous divorces } \\
\hline Groom & 0.374 & 0.484 & 0.373 & 0.484 & 0.375 & 0.484 \\
\hline Bride & 0.369 & 0.483 & 0.367 & 0.482 & 0.371 & 0.483 \\
\hline One partner & 0.253 & 0.435 & 0.253 & 0.435 & 0.254 & 0.435 \\
\hline Both partners & 0.241 & 0.428 & 0.239 & 0.427 & 0.243 & 0.439 \\
\hline
\end{tabular}

\section{Determinants of the choice to covenant marry}

The comparison of covenantly and traditionally married populations provides some insight into the differences among individuals and couples who choose each of these marriage options. But, it is only a first step in understanding why individuals may choose one marriage type over another. An estimation of the demand for covenant marriages more precisely measures what matters to the decision to covenant marry. The following logit estimation for the marriage type decision determines what individual and couple characteristics systematically affect the type of marriage chosen. The dependant variable in the following regression analysis indicates 
whether a covenant marriage was chosen - it equals 1 if the couple married with a covenant and 0 otherwise (the couple chose the traditional option). The independent variables include both individual and couple characteristics. The individual characteristics include the bride's and groom's ages, education levels, and race, as well as a dummy indicating whether the bride or groom lived in an urban area before the union. The indicator of race is a dummy variable signifying whether or not each individual in the couple is white, it is 1 if so and 0 otherwise. The dummy variable indicating where each individual resided is 1 if it was in an urban area and 0 otherwise.

To address the prior that these marriages are driven by religion, the type of ceremony (religious or civil) with which the couple married was included. Though not a perfect indicator of how religious the couple is or to what religion they subscribe, this is a proxy for religiosity. This requires the simple assumption that more religious people will opt for a religious ceremony. The inclusion of the civil ceremony dummy variable will shed light on whether or not religiousness is driving the covenant marriage decision. Variables indicating whether one or both partners have been previously divorced are incorporated. It is reasonable to believe that previous divorce may affect one's decision to make a marriage more binding.

Finally, there are several variables that measure the similarity or differences within couples, these are the variables whose effects will allow for comment on the reason for covenant usage. Specifically, if less similar individuals are more likely to covenant marry, we can reject that they are being used as a signaling or screening device, making their use as a commitment device more likely. These variables include the difference in the partners' ages, education levels, race, and place of premarriage residence.

The couple's decision to marry with a covenant was estimated three ways. The first estimate includes all the variables previously discussed. The second adds parish level controls. Including a series of parish dummy variables will abstract from any regional differences that may matter to the covenant decision. The final specification includes parish divorce rates to control for the potential influence that this may have on a couple's covenant decision. High divorce rates among those couples surrounding the decision makers may make them more likely to engage in a covenant - they want to make their marriage last. On the other hand, they are more likely to bear witness to the already high costs associated with divorce and may decide that a covenant is a bad idea. Both are plausible effects, so this remains an empirical question. The results of the three different specifications for this model are presented in Table 7.

First of all, we can be relatively confident in the directions of the estimated effects, because their signs are consistent for all three specifications. Furthermore, these logit results of Louisiana marriages reinforce some of the findings of the previous means comparisons. Couples that wed with a civil rather than religious ceremony are less likely to marry with a covenant. This supports the idea that the choice to engage in these stricter marriages may be driven by religion. The magnitude and significance of this effect shrinks when parish controls are added. And the effect is statistically insignificant when parish divorce rates are included in the estimation. Couples are more likely to choose the covenant marriage option if they are younger and, interestingly, if they are more educated. Being white has a positive effect on the decision to covenant marry; this effect is statistically significant for the groom in the first two specifications and for the bride in only the first one. Finally, couples where the groom resides in an urban area are more likely to use a covenant, but the bride residing in an urban area makes a couple less likely to use the stricter marriage. 
Table 7 The decision to covenant marry, Louisiana (1997-2003)

\begin{tabular}{|c|c|c|c|c|c|c|}
\hline & \multicolumn{2}{|c|}{ Basic model } & \multicolumn{2}{|c|}{ With parish controls } & \multicolumn{2}{|c|}{ With parish divorce rates } \\
\hline & Coefficient & $\begin{array}{l}\text { Marginal } \\
\text { effect }(\%)\end{array}$ & Coefficient & $\begin{array}{l}\text { Marginal } \\
\text { effect }(\%)\end{array}$ & Coefficient & $\begin{array}{l}\text { Marginal } \\
\text { effect }(\%)\end{array}$ \\
\hline Civil ceremony & $\begin{array}{c}-0.133^{* * * *} \\
(0.049)\end{array}$ & 0.11 & $\begin{array}{l}-0.122^{* *} \\
(0.049)\end{array}$ & -0.09 & $\begin{array}{r}-0.077 \\
(0.060)\end{array}$ & -0.06 \\
\hline \multicolumn{7}{|l|}{ Resides in an urban area } \\
\hline Groom & $\begin{array}{l}0.435^{* * *} * \\
(0.092)\end{array}$ & 0.38 & $\begin{array}{l}0.322 * * * \\
(0.094)\end{array}$ & 0.24 & $\begin{array}{l}0.498^{* * *} \\
(0.112)\end{array}$ & 0.41 \\
\hline Bride & $\begin{array}{c}-0.230^{* *} \\
(0.091)\end{array}$ & -0.20 & $\begin{array}{c}-0.313 * * * \\
(0.093)\end{array}$ & -0.23 & $\begin{array}{c}-0.199^{*} \\
(0.110)\end{array}$ & -0.16 \\
\hline Difference & $\begin{array}{l}0.837 * * * \\
(0.122)\end{array}$ & 1.05 & $\begin{array}{l}0.778 * * * \\
(0.124)\end{array}$ & 0.82 & $\begin{array}{l}0.797 * * * \\
(0.150)\end{array}$ & 0.92 \\
\hline \multicolumn{7}{|l|}{ Race } \\
\hline Groom is white & $\begin{array}{l}0.378 * * \\
(0.176)\end{array}$ & 0.31 & $\begin{array}{l}0.355^{* *} \\
(0.176)\end{array}$ & 0.25 & $\begin{array}{c}0.121 \\
(0.219)\end{array}$ & 0.10 \\
\hline Bride is white & $\begin{array}{c}0.296^{*} \\
(0.176)\end{array}$ & 0.24 & $\begin{array}{c}0.272 \\
(0.176)\end{array}$ & 0.19 & $\begin{array}{c}0.333 \\
(0.219)\end{array}$ & 0.26 \\
\hline Couple is interracial & $\begin{array}{c}-0.277 \\
(0.171)\end{array}$ & -0.21 & $\begin{array}{c}-0.204 \\
(0.172)\end{array}$ & -0.14 & $\begin{array}{c}-0.377 * \\
(0.212)\end{array}$ & -0.26 \\
\hline \multicolumn{7}{|c|}{ Education (absolute value of years) } \\
\hline Groom & $\begin{array}{l}0.101 * * * \\
(0.013)\end{array}$ & 0.09 & $\begin{array}{l}0.095 * * * \\
(0.014)\end{array}$ & 0.07 & $\begin{array}{l}0.119 * * * \\
(0.016)\end{array}$ & 0.10 \\
\hline Bride & $\begin{array}{l}0.123^{* * * *} \\
(0.013)\end{array}$ & 0.11 & $\begin{array}{l}0.118^{* * * *} \\
(0.014)\end{array}$ & 0.09 & $\begin{array}{l}0.122^{* * *} \\
(0.017)\end{array}$ & 0.10 \\
\hline Difference & $\begin{array}{l}0.063^{* * *} \\
(0.016)\end{array}$ & 0.05 & $\begin{array}{l}0.062 * * * \\
(0.016)\end{array}$ & 0.05 & $\begin{array}{l}0.073^{* * *} \\
(0.020)\end{array}$ & 0.06 \\
\hline \multicolumn{7}{|c|}{ Age (absolute value of years) } \\
\hline Groom & $\begin{array}{c}-0.014^{* *} \\
(0.006)\end{array}$ & -0.01 & $\begin{array}{c}-0.011^{*} \\
(0.006)\end{array}$ & -0.01 & $\begin{array}{c}-0.017^{* *} \\
(0.008)\end{array}$ & -0.01 \\
\hline Bride & $\begin{array}{c}-0.020 * * * \\
(0.006)\end{array}$ & -0.02 & $\begin{array}{c}-0.017 * * * \\
(0.006)\end{array}$ & -0.01 & $\begin{array}{c}-0.023^{* * *} \\
(0.007)\end{array}$ & -0.02 \\
\hline Difference & $\begin{array}{c}-0.007 \\
(0.008)\end{array}$ & -0.01 & $\begin{array}{c}-0.008 \\
(0.008)\end{array}$ & -0.01 & $\begin{array}{c}-0.001 \\
(0.010)\end{array}$ & 0.00 \\
\hline \multicolumn{7}{|l|}{ Previous divorces } \\
\hline One partner & $\begin{array}{c}0.050 \\
(0.068)\end{array}$ & 0.04 & $\begin{array}{c}0.006 \\
(0.069)\end{array}$ & 0.00 & $\begin{array}{c}0.099 \\
(0.084)\end{array}$ & 0.08 \\
\hline Both partners & $\begin{array}{c}0.149^{*} \\
(0.083)\end{array}$ & 0.13 & $\begin{array}{c}0.017 \\
(0.083)\end{array}$ & 0.01 & $\begin{array}{c}0.198^{*} \\
(0.105)\end{array}$ & 0.17 \\
\hline Parish divorce rate & $\ldots$ & & $\ldots$ & & $\begin{array}{l}0.235^{* * *} \\
(0.028)\end{array}$ & 0.19 \\
\hline Constant & $\begin{array}{c}-7.212^{* * *} \\
(0.202)\end{array}$ & & $\begin{array}{c}-7.907 * * * \\
(0.373)\end{array}$ & & $\begin{array}{c}-8.170^{* * *} \\
(0.282)\end{array}$ & \\
\hline Adjusted $R^{2}$ & 0.040 & & 0.070 & & 0.047 & \\
\hline Observations & 155681 & & 155233 & & 105133 & \\
\hline
\end{tabular}

Note: $* * * * *$ and $*$ indicate significance at the 1,5 and $10 \%$ levels.

In terms of differences between individuals within couples, the results indicate that couples that are less similar are more likely to choose a covenant marriage. This is evidence against covenants being used for signaling or screening, and in favor of the commitment device explanation. First of all, differences in residence (one individual living in an urban area and one not) make a couple more likely to marry with a covenant. This effect is significant at the 1 percent level in all three specifications and 
is relatively large. The marginal effect is around 1 percent in each model, meaning couples that reside in different types of areas before marriage are twice as likely to marry with a covenant (the 1 percent increase in the probability of using a covenant doubles the likelihood since the base covenant rate use is approximately 1 percent). Second, differences in years of education make it significantly more likely a couple will use the covenant option. The marginal effect is much smaller than that for residence differences, but the 0.05 percent increase in probability reported is for a year of difference in education. In the context of differences in education level the effect grows. Finally, the two differences that have a negative effect on the covenant decision, differences in age and race, are generally not statistically significant. The exception is the effect of a couple being interracial in the third specification of this decision model, it is significant at the 10 percent level.

The effect of divorce on covenant usage is generally positive, both in terms of previous divorces within the couple and the surrounding divorce rate. Both members of the couple having at least one previous divorce has a positive (and in two out of the three specifications, a significant) effect on the probability that a couple chooses a covenant marriage. Furthermore, the current divorce rate in the parish where the couple marries has a positive and significant effect on this decision. It may be that the positive effect of previous and surrounding divorces indicates that individuals are acutely aware of their time inconsistent preferences and are choosing a commitment device to curtail future divorce. On the other hand, individuals with prior divorce experience may be more likely to screen potential partners, in hopes of avoiding divorce.

As previously mentioned, there might have been an initially high demand for this option as previously married couples chose to change the status of their existing marriage. Because this decision is fundamentally different than the one considered in this analysis and there is no way with this data to identify couples who are renewing their vows, the following estimates try to account for any effects caused by this "pent-up" demand. Early years of covenant availability were systematically dropped from the population of Louisiana marriages, and the previous analysis was applied to each subgroup. Table 8 summarizes the analysis of the covenant decision for marriages during and after 1998, 1999, and 2000. In other words, the first two columns display the result for all marriages except for those occurring in the first 6 months of the options availability, in the next two columns were the first year and a half of marriages omitted, and in the last two columns the first two and a half years of marriages with this option were left out of the analysis.

There are two significant differences in the results - the effect of ceremony type and the effect of prior divorce(s) on covenant usage. First, recall the original analysis found that couples using a civil ceremony were less likely to engage in a covenant marriage. When accounting for couples who are renewing their vows, this effect not only disappears, but is opposite. By excluding those married in the first 6 months of covenant availability, the effect of having a civil ceremony loses significance. When the first year and a half of marriages are omitted, the effect of having a civil ceremony is positive and significant at the 1 percent level. The marginal effect of having a civil ceremony after 2000 is 0.96 percent, which nearly doubles the likelihood that a couple will marry with a covenant. This is evidence that the covenant decision is not driven by religiosity. Second, there is an increase in the rate at which previously divorced people choose covenants. This is true even controlling for parish divorce rates. This indicates that there may be something about personal experience of divorce that makes people prefer stricter marriage contracts. 
Table 8 Covenant marriage decision without early years, Louisiana (1997-2003)

\begin{tabular}{|c|c|c|c|c|c|c|}
\hline & \multicolumn{2}{|c|}{$1998-2003$} & \multicolumn{2}{|c|}{$1999-2003$} & \multicolumn{2}{|c|}{$2000-2003$} \\
\hline & Coefficient & $\begin{array}{l}\text { Marginal } \\
\text { effect }(\%)\end{array}$ & Coefficient & $\begin{array}{l}\text { Marginal } \\
\text { effect }(\%)\end{array}$ & Coefficient & $\begin{array}{l}\text { Marginal } \\
\text { effect }(\%)\end{array}$ \\
\hline Civil ceremony & $\begin{array}{c}-0.037 \\
(0.063)\end{array}$ & -0.03 & $\begin{array}{l}0.365^{* * * *} \\
(0.078)\end{array}$ & 0.27 & $\begin{array}{l}1.951 * * * \\
(0.176)\end{array}$ & 0.96 \\
\hline \multicolumn{7}{|c|}{ Resides in an urban area } \\
\hline Groom & $\begin{array}{l}0.531 * * * \\
(0.118)\end{array}$ & 0.44 & $\begin{array}{l}0.471 * * * \\
(0.136)\end{array}$ & 0.36 & $\begin{array}{l}0.472 * * * \\
(0.163)\end{array}$ & 0.27 \\
\hline Bride & $\begin{array}{c}-0.133 \\
(0.116)\end{array}$ & -0.11 & $\begin{array}{c}-0.143 \\
(0.134)\end{array}$ & -0.11 & $\begin{array}{c}-0.161 \\
(0.160)\end{array}$ & -0.09 \\
\hline Difference & $\begin{array}{l}0.800^{* * * *} \\
(0.157)\end{array}$ & 0.93 & $\begin{array}{l}0.721^{* * * *} \\
(0.183)\end{array}$ & 0.75 & $\begin{array}{l}0.819^{* * *} \\
(0.216)\end{array}$ & 0.67 \\
\hline \multicolumn{7}{|l|}{ Race } \\
\hline Groom is white & $\begin{array}{c}0.072 \\
(0.226)\end{array}$ & 0.06 & $\begin{array}{c}0.086 \\
(0.242)\end{array}$ & 0.06 & $\begin{array}{c}0.117 \\
(0.289)\end{array}$ & 0.06 \\
\hline Bride is white & $\begin{array}{c}0.399^{*} \\
(0.226)\end{array}$ & 0.31 & $\begin{array}{c}0.409^{*} \\
(0.242)\end{array}$ & 0.29 & $\begin{array}{c}0.462 \\
(0.289)\end{array}$ & 0.25 \\
\hline Couple is interracial & $\begin{array}{c}-0.375^{*} \\
(0.219)\end{array}$ & -0.26 & $\begin{array}{c}-0.221 \\
(0.235)\end{array}$ & -0.15 & $\begin{array}{c}-0.115 \\
(0.281)\end{array}$ & -0.06 \\
\hline \multicolumn{7}{|c|}{ Education (absolute value of years) } \\
\hline Groom & $\begin{array}{l}0.120^{* * *} \\
(0.017)\end{array}$ & 0.10 & $\begin{array}{l}0.142^{* * * *} \\
(0.020)\end{array}$ & 0.11 & $\begin{array}{l}0.119^{* * *} \\
(0.024)\end{array}$ & 0.07 \\
\hline Bride & $\begin{array}{l}0.118^{* * * *} \\
(0.017)\end{array}$ & 0.10 & $\begin{array}{l}0.099^{* * * *} \\
(0.020)\end{array}$ & 0.07 & $\begin{array}{l}0.053 * * \\
(0.024)\end{array}$ & 0.03 \\
\hline Difference & $\begin{array}{l}0.078^{* * * *} \\
(0.020)\end{array}$ & 0.06 & $\begin{array}{l}0.078 * * * \\
(0.024)\end{array}$ & 0.06 & $\begin{array}{l}0.073 * * \\
(0.028)\end{array}$ & 0.04 \\
\hline \multicolumn{7}{|c|}{ Age (absolute value of years) } \\
\hline Groom & $\begin{array}{c}-0.021^{* * *} \\
(0.008)\end{array}$ & -0.02 & $\begin{array}{c}-0.017^{*} \\
(0.009)\end{array}$ & -0.01 & $\begin{array}{c}-0.020^{*} \\
(0.011)\end{array}$ & -0.01 \\
\hline Bride & $\begin{array}{l}-0.022 * * * \\
(0.008)\end{array}$ & -0.02 & $\begin{array}{c}-0.022^{* *} \\
(0.009)\end{array}$ & -0.02 & $\begin{array}{c}-0.018^{*} \\
(0.011)\end{array}$ & -0.01 \\
\hline Difference & $\begin{array}{c}0.001 \\
(0.010)\end{array}$ & 0.00 & $\begin{array}{r}-0.006 \\
(0.012)\end{array}$ & 0.00 & $\begin{array}{c}0.000 \\
(0.014)\end{array}$ & 0.00 \\
\hline \multicolumn{7}{|l|}{ Previous divorces } \\
\hline One partner & $\begin{array}{c}0.117 \\
(0.087)\end{array}$ & 0.10 & $\begin{array}{c}0.096 \\
(0.102)\end{array}$ & 0.07 & $\begin{array}{l}0.303^{* *} \\
(0.123)\end{array}$ & 0.18 \\
\hline Both partners & $\begin{array}{l}0.214^{* *} \\
(0.110)\end{array}$ & 0.18 & $\begin{array}{c}0.235^{*} \\
(0.126)\end{array}$ & 0.19 & $\begin{array}{l}0.524 * * * \\
(0.152)\end{array}$ & 0.34 \\
\hline Parish divorce rate & $\begin{array}{l}0.268 * * * \\
(0.031)\end{array}$ & 0.22 & $\begin{array}{l}0.299^{* * *} \\
(0.040)\end{array}$ & 0.22 & $\begin{array}{l}0.248^{* * *} \\
(0.051)\end{array}$ & 0.14 \\
\hline Constant & $\begin{array}{c}-8.265^{* * *} \\
(0.297)\end{array}$ & & $\begin{array}{c}-8.801 * * * \\
(0.358)\end{array}$ & & $\begin{array}{c}-9.276^{* * *} \\
(0.458)\end{array}$ & \\
\hline Adjusted $R^{2}$ & 0.050 & & 0.052 & & 0.078 & \\
\hline Observations & 94848 & & 75341 & & 53743 & \\
\hline
\end{tabular}

Note: $* * * * *$ and $*$ indicate significance at the 1,5 and $10 \%$ levels.

In order to test whether these findings are robust beyond Louisiana, a similar analysis was used to determine what influences the decision to marry with a particular type of contract in Arkansas. Recall the data from Arkansas is limited in scope. The only available information about couples beyond the type of marriage they chose is age. This allows for a very limited estimation of what couple and 
Table 9 How age affects the covenant choice in Arkansas and Louisiana

\begin{tabular}{|c|c|c|c|c|}
\hline & \multicolumn{2}{|c|}{ Arkansas (2001-2003) } & \multicolumn{2}{|c|}{ Louisiana (1997-2003) } \\
\hline & Coefficient & $\begin{array}{l}\text { Marginal } \\
\text { effect }(\%)\end{array}$ & Coefficient & $\begin{array}{l}\text { Marginal } \\
\text { effect }(\%)\end{array}$ \\
\hline \multicolumn{5}{|c|}{ Age (absolute value of years) } \\
\hline Groom & $\begin{array}{c}0.001 \\
(0.006)\end{array}$ & 0.00 & $\begin{array}{l}-0.04 \\
(0.005)\end{array}$ & 0.00 \\
\hline Bride & $\begin{array}{c}-0.014 * * \\
(0.006)\end{array}$ & -0.02 & $\begin{array}{l}-0.021 * * * \\
(0.005)\end{array}$ & 0.00 \\
\hline Difference & $\begin{array}{l}-0.028 * * * \\
(0.006)\end{array}$ & -0.03 & $\begin{array}{c}-0.021 * * * \\
(0.006)\end{array}$ & 0.00 \\
\hline Constant & $\begin{array}{l}-2.290 * * * \\
(0.075)\end{array}$ & & $\begin{array}{c}-4.35^{* * *} \\
(0.251)\end{array}$ & \\
\hline Adjusted $R^{2}$ & 0.0353 & & 0.042 & \\
\hline Observations & 77962 & & 232879 & \\
\hline
\end{tabular}

Note: $* * * * *$ and $*$ indicate significance at the 1,5 and $10 \%$ levels.

individual characteristics influence the decision to use a covenant. The first two columns in Table 9 report the results for an estimation of how individual ages and the age difference within the couple affect the probability that a couple chooses a covenant rather than a traditional marriage.

The results are consistent with those from the Louisiana marriage data in terms of bride's age. As in Louisiana, an additional year of age for an Arkansas bride has a significant negative effect on the probability a covenant will be chosen. The effect of the groom's age in Arkansas is close to zero and insignificant. The age difference between the bride and the groom in Arkansas also effects the decision to marry with a covenant negatively and in Arkansas the effect is significant. In order to test whether this is an actual difference or simply a consequence of limited explanatory variables, the analysis was replicated using the Louisiana data. When you limit the explanation of the variation in covenant use to only the age variables in Louisiana, the difference in the couple's ages is significant also.

\section{CONCLUDING REMARKS AND REMAINING QUESTIONS}

This paper analyzes who is marrying with covenant marriages and considers why they might be willing to incur the additional costs associated with this stricter union. This paper finds that there are significant differences between the couples who marry with a covenant and those who choose the traditional option. These differences exist both theoretically and empirically. The empirical analysis finds (1) that younger, yet more educated, individuals are marrying with covenants, (2) evidence that couples are likely using the covenant as a commitment rather than signaling device, and (3) religion may not play a large part in the decision. Since the goal of a covenant is to decrease the probability of divorce, it may be concerning that younger couples are marrying this way and likely using the institution as a commitment device. And if the stricter vows are taken by younger couples who are more different (as the data suggests), perhaps only costlier court proceedings will result from this contract's availability. Interestingly, the data also suggest that divorce rates may play an 
important role in the use of this new marriage option - high rates of divorce induce couples to opt for the stronger union. Finally, the analysis finds that religion is not significant in the decision to marry with a covenant.

This paper acts as a first step in understanding this new type of marriage and its effects on couples and society. Further exploration of what determines covenant marriage usage should consider that factors such as unemployment, poverty, or fertility rates may affect how couples view this option. Just as important as why individuals choose covenant marriages, is what are the effects of this policy. The next step is to explore the effect of this policy on divorces and marriages. Addressing how covenants are chosen gives some insight into whether this marriage option will be effective in its goals (combating growing divorce rates), but future analysis can measure this directly with changing divorce rates. Furthermore, the effects of the covenant marriage policy are not limited to only those who partake in the new covenant arrangement. The existence of a new type of marriage has the potential to affect individuals in other commitment arrangements [Drewianka 2004]. Future research will not only look at whether or not covenants are effective in their goal of decreasing divorce rates, but will also consider how covenant marriages affect the rate at which couples marry traditionally and cohabitate.

\section{Acknowledgements}

For comments, I am grateful to Kaushik Basu, Deb DeGraff, Scott Drewianka, Ted O'Donoghue and the participants of the Economics Department Seminar Series at the University of Wisconsin, Milwaukee, the 2006 conference on Understanding and Informing Policy Design - Association for Public Policy and Management, the Imagining Public Policy to meet Women's Economic Security Needs conference in Vancouver, the 2007 Eastern Economic Association Meeting, the 2006 Midwest Economic Association Meeting, the 2006 Southwest Economic Association Meeting, the 2008 Western Social Science Association Meeting and the Lake Forest College Economics Department Seminar Series. Finally, I am grateful to two anonymous referees and an editor for many useful comments and suggestions.

\section{Notes}

1. Wolfers offers a thorough summary of this ongoing debate and finds evidence that the shift to unilateral divorce laws caused an initial spike in divorce rates that dissipated over time [Wolfers 2006].

2. It is true that individuals who are more religious, conservative, and traditional in terms of their views of gender roles tend to be the biggest proponents of covenant marriages. The original version of the Louisiana covenant marriage proposal allowed divorce only in the circumstances of adultery and abandonment, which are biblical in origin.

3. Interestingly, it may be welfare increasing for governments to provide such benefits if they think covenant marriages increase stability and there are positive externalities associated with stable families.

4. As Becker [1974] points out, these investments will lead to greater marital surplus.

5. If covenants were not an effective screening mechanism then no one would choose to engage in such an arrangement in this framework. Individuals would not be willing to increase the costs of a potential divorce without the benefits of eliciting more information before marriage. Since covenant marriages are taking place, we can assume that it induces truthful signaling.

6. For simplicity, this framework considers signaling/screening for levels of dedication, but realistically it would apply to signaling or screening for any unobservable characteristic.

7. This cannot be identified in the data, but will be addressed in the following subsection, by considering the demand for covenant marriage without the earliest years of availability. 
8. All data used in this paper are from Louisiana residents. Non-resident couples married in New Orleans are omitted, because the decision to marry with a covenant will not carry the same costs when they return to their home state (which likely does not have the covenant option).

9. This is not surprising because it follows the nationwide trend that couples are waiting longer to marry. Similarly, it makes sense that there are more interracial couples in the more recent time period. Beyond the scope of this paper is the interesting question: how much of this trend can be attributed to the passage of covenant marriage legislation?

\section{References}

Becker, Gary. 1974. A Theory of Marriage, in Economics of the Family, edited by T.W. Schultz. Chicago, IL: University of Chicago Press.

Camerer, Colin, Samuel Issacharoff, George Loewenstein, Ted O’Donoghue, and Mattew Rabin. 2003. Regulation for Conservatives: Behavioral Economics and the Case for "Asymmetric Paternalism". University of Pennsylvania Law Review, 151(3): 1211-1254.

Cook, Joe. 1998. No to Covenant Marriage. World and I Magazine, 13: 10-14.

Divorce Rates by Parish of Occurrence, Louisiana. 1998-2002. Louisiana Vital Statistics Publication. Louisiana: Office of Public Health.

Drewianka, Scott. 2004. How will Reforms of Marital Institutions Influence Marital Commitment? A Theoretical Analysis. Review of Economics of the Household, 2: 303-323.

Hamm, Marie Summerlin. 1999. Opportuning Virtue: The Binding Ties of Covenant Marriage Examined. Regent University Law Review, 12: 73-90.

Leon, Kim. 2004. Covenant Marriage: What it is and does it work? http://missourifamilies.org/features/ divorcearticles/divorcefeature23.htm.

Loewenstein, George. 2000. Emotions in Economic Theory and Economic Behavior. American Economic Review, 90(2): 426-432.

Loewenstein, George, Ted O'Donoghue, and Matthew Rabin. 2003. Projection Bias in Predicting Future Utility. Quarterly Journal of Economics, 118(4): 1209-1248.

Louisiana Health Profiles. 1998-2002. Louisiana Vital Statistics Publication. Louisiana: Office of Public Health.

Mayer, Nancy. 1999. Oregon debates divorce vs commitment: Who's Right? http://listarchives.his.com/ smartmarriages/smartmarriages.9907/msg00034.html.

O’Donoghue, Ted, and Matthew Rabin. 2003. Self-Awareness and Self-Control, in Time and Decision, edited by George Loewenstein, Daniel Read, and Roy Baumeister. New York: Russell Sage Foundation.

State of Louisiana Vital Records Marriage System. 1990-2003. Louisiana: State of Louisiana Department of Health and Hospitals.

Wolfers, Justin. 2006. Did Unilateral Divorce Laws Raise Divorce Rates? A Reconciliation and New Results. The American Economic Review, 96(5): 1802-1820.

The First Covenant Debate. 1947. The First Covenant Marriage Proposal: Debate on Mazeaud Proposal in the French Civil Code Reform Commission, 1947 (translated by John Crouch), Part of the Divorce Reform Page, sponsored by Americans for Divorce Reform, http://www.divorcereform.org/maz.html. 